\title{
ANALYSIS OF CHANGES IN WATER MANAGEMENT LIGHT SOIL FOLLOWING APPLICATION OF DIFFERENT TILLAGE SYSTEMS AND FORECROPS
}

\section{ANALIZA ZMIAN W GOSPODARCE WODNEJ GLEBY LEKKIEJ W NASTEPSTWIE STOSOWANIA ZRÓŻNICOWANYCH SYSTEMÓW UPRAWY I PRZEDPLONÓW}

\author{
Department of Agronomy, West Pomeranian University of Technology, Szczecin, Poland \\ ${ }^{1}$ Department of Meteorology and Shaping Landscape Architecture, West Pomeranian University \\ of Technology, Szczecin, Poland
}

\begin{abstract}
Streszczenie. Badania przeprowadzono w latach 2006-2008 jako kontynuację doświadczenia statycznego założonego w 1993 roku w Rolniczej Stacji Doświadczalnej Lipnik (k. Stargardu Szczecińskiego). Doświadczenie polowe, dwuczynnikowe, założono w układzie pasów prostopadłych losowanych podbloków, w czterech powtórzeniach. Badanymi czynnikami były systemy uprawy roli stosowane pod pszenicę ozimą po różnych przedplonach (bobik, burak cukrowy). Wpływ przedplonu na właściwości fizyczne gleby lekkiej, związany z gospodarką wodną, był uzależniony od wielkości opadów w sezonie wegetacji. W latach o większych niedoborach opadów gleba na stanowisku po bobiku charakteryzowała się większą gęstością, wilgotnością aktualną oraz porowatością niekapilarną, natomiast na stanowisku po burakach dotyczyło to porowatości aeracyjnej. W latach o mniejszych niedoborach opadów na stanowisku po burakach zwiększona była gęstość objętościowa, natomiast w stanowisku po bobiku - porowatość niekapilarna. Rezygnacja z orki siewnej na korzyść systemu bezpłużnego lub siewu bezpośredniego modyfikuje niektóre właściwości fizyczne wierzchnich warstw gleby. Zaobserwowano wzrost gęstości objętościowej oraz porowatości niekapilarnej. Większe wartości gęstości objętościowej gleby, notowane na obiektach, na których stosowano technologie bezorkowe (zwłaszcza na glebach lekkich), mogą sprzyjać wzrostowi i rozwojowi roślin towarowych, w tym pszenicy ozimej.
\end{abstract}

Key words: tillage systems, forecrop, winter wheat, physical properties of soil.

Słowa kluczowe: systemy uprawy roli, przedplon, pszenica ozima, fizyczne właściwości gleby.

\section{INTRODUCTION}

The use of simplifications in tillage is usually on the elimination of plowing the applied treatments for the seed of a particular plant species. Therefore, the plowless systems, consisting in loosening the top layer of soil (using a cultivator) and system of a direct sowing, appeared. An indispensable element determining the growth, development, and yielding of crops, in addition to fertilization, irrigation, agro-technical deadlines, is appropriate soil preparation for crop sowing. Water content of the soil is its life and plant vegetation attribute.

Corresponding author - Adres do korspondencji: Cezary Podsiadło, Department of Agronomy, West Pomeranian University of Technology, Szczecin, Juliusza Słowackiego 17, 71-434 Szczecin, Poland, e-mail: Cezary.Podsiadlo@zut.edu.pl 
Water retention in the soil is related to the complex factors of soil and climate character. To some extent, the amount of water accumulated in the soil is also determined by its tillage, e.g. to perform the post-harvest cultivation of stubble protects the field against unnecessary water loss, rolling favors the water infiltration from deeper layers to desiccated surface layers (Pabin et al. 2002). Study of the effects of tillage on soil physical properties (bulk density, moisture content, conciseness and field water consumption), conducted among Blecharczyk et al. (2004), Dzienia and Wereszczaka 2002 Hryńczuk and Weber (2005), Kordas and Klima (2005), Pabin et al. (2002, 2007), Rokosz and Podsiadło (2015). They proved that direct seeding will help increase firmness and density of the soil, compared with conventional tillage (classical) and no-tillage. Mechanical tillage in the first instance affect the bulk density, which largely determines the management of water affects the intensity of the process of wetting and drying and, consequently, the soil moisture (Włodek et al. 2007). The aim of the study was to analyze changes in selected physical properties of light soil, shaping its water management in the aftermath of the use of different cropping systems and previous cropping.

\section{MATERIAL AND METHODS}

The study was conducted in a long-termi field experiment, founded in 1993 in the Agricultural Experimental Station in Lipnik (near Stargard Szczeciński). Localization of the station in the central part of Szczecin Lowland ( $\varphi 5^{0} 21^{`} \mathrm{~N}, \lambda 14^{0} 58^{\circ} \mathrm{E}$, Hs 30 m.a.s.I.) and the soil conditions make that measurement results are representative for the whole region, and even for western part of West Pomerania. Bi-factorial field experiment was established in the perpendicular bands pattern of randomized sub-blocks in four replicates. The studied factor consisted of tillage systems used for winter wheat cultivation after different forecrops (faba beans, sugar beet). Surface of the plot for harvest was $30 \mathrm{~m}^{2}$. The first-order factor (tillage system): A - plowing tillage - classic tillage used for winter crops, B - plowless tillage cultivator + string roller, $\mathrm{C}$ - direct sowing - seeder for direct sowing. The second-order factor (forecrop): 1 - faba bean (self-completing 'Martin' cv.), 2 - sugar beet ('Kutnowska' cv.) good rye complex and IVb bonitation class.

The winter wheat of 'Cobra Plus' cv. was sown in the experiment within the period recommended by agrotechnical procedures for Western Pomerania. For objects with conventional $(A)$ and plowless tillage $(B)$, wheat was sown using row cereal seeder. In contrast, on objects with direct sowing, a special seeder (for direct sowing) was applied. The experiment was founded on light soil of good rye complex and IVb bonitation class - Soil Taxonomy Polish (2011). The soil was developed from light loamy sand (p/g), with weak loamy sand underneath ( $p s g)$, and light silt in some spots $(g /)$. In typological terms, this soil is counted to brown soils. Thickness of the humus layer is $14-25 \mathrm{~cm}$, humus content amounts to $1.3-1.5 \%$. Content of alluvial parts $11-13 \%, \mathrm{pH}_{\mathrm{KCL}} 6.0$, average content of $\mathrm{K}-105 \mathrm{mg} \cdot \mathrm{kg}^{-1}$ soil, $\mathrm{P}-79 \mathrm{mg} \cdot \mathrm{kg}^{-1}$ soil. In terms of agronomical categories, the soil is typical for West Pomerania region. 
Soil samples to determine selected physical properties of soil were collected in the years 2006-2008 from 0-10, 10-20, 20-30 cm soil layers using Kopecky's cylinders of $100 \mathrm{~cm}^{3}$ capacity at the phase of tillering, flowering, and full ripeness of winter wheat $\mathrm{BBCH}$ scale, with four replicates of each plot. Among parameters of soil water management, there were:

- bulk density:

$$
\mathrm{S}_{\mathrm{o}}=\frac{(d-e)}{v}\left[\mathrm{Mg} \cdot \mathrm{cm}^{3}\right]
$$

- current humidity:

$$
\text { Wav }=\frac{(a-d)}{v} \cdot 100[\%]
$$

- capillary water capacity:

$$
\mathrm{Kpw}=\frac{(b-d)}{v} \cdot 100[\%]
$$

- maximum water capacity:

$$
\mathrm{Mpw}=\frac{(c-d)}{v} \cdot 100[\%]
$$

- non-capillary porosity:

$$
\text { Pnk = Mpw }-\mathrm{Kpw}[\%] \text {; }
$$

- aeration porosity:

$$
\mathrm{Pa}=\mathrm{Mpw}-\mathrm{Wav}[\%] \text {; }
$$

where:

$a$ - weight of cylinder with fresh soil,

$b$ - weight of cylinder with capillary-saturated soil,

$c$ - weight of cylinder with totally saturated soil,

$d$ - weight of cylinder with soil dried at $105^{\circ} \mathrm{C}$,

$e-$ weight of empty cylinder (tare),

$v$ - capacity of cylinder $\left(100 \mathrm{~cm}^{3}\right)$.

In all the years of research applied before sowing wheat, fertilization with nitrogen, phosphorus and potassium, respectively, in quantities of 24,80 , and $120 \mathrm{~kg} \cdot \mathrm{ha}^{-1}$. In the spring after the start of vegetation used only nitrogen fertilization, dividing them into two doses. Plant protection treatments were applied in accordance with the recommendations of agricultural technology used in the cultivation of winter wheat.

The study results were statistically processes using variance analysis for multi-year experiments, and difference significance at the level of $\alpha-0.05$ was evaluated applying Tukey test in FR-ANALWAR 4.3 software based on Microsoft Excel (Rudnicki 2011).

Table 1 shows the average monthly temperatures and their deviation (in ${ }^{\circ} \mathrm{C}$ ) from the multi-year average of 1961 to 2000 and the classification of the thermal months Lorenc (2000) based on a standard deviation. Precipitation is characterized by the scale developed by Kaczorowska (1962), taking into account the percentage of rainfall in a given month in relation to the value of multi-year. Among the analyzed period of years, where the average monthly air temperature considerably exceeded the standard began in June 2006 and lasted until mid-2007 hottest and at the same time extremely dry was July 2006. 
Table 1. Average monthly air temperature and precipitation in 2005-2008, together with a deviation from the norm (1961-2000) at the agrometeorological station in Lipnik

Tabela 1. Średnia miesięczna temperatura powietrza i sumy opadów atmosferycznych $w$ latach 2005-2008, wraz z odchyleniem od normy (1961-2000), w stacji agrometeorologicznej w Lipniku

\begin{tabular}{|c|c|c|c|c|c|c|c|c|c|c|c|c|c|c|}
\hline & \multirow{2}{*}{$\begin{array}{c}\text { Rok/ } \\
\text { odchylenie } \\
\text { od normy } \\
\text { Year/deviation } \\
\text { from the norm }\end{array}$} & \multicolumn{13}{|c|}{ Month - Miesiąc } \\
\hline & & I & II & III & IV & V & $\mathrm{VI}$ & VII & VIII & IX & $x$ & $\mathrm{XI}$ & XII & I-XII \\
\hline \multirow{12}{*}{ 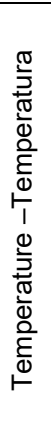 } & 2005 & & & & & & & & & 15,6 & 10,2 & 4,2 & 1,2 & \\
\hline & odchylenie & & & & & & & & & 2.3 & 1.4 & 0.4 & 0.8 & \\
\hline & deviation $\left[{ }^{\circ} \mathrm{C}\right]$ & & & & & & & & & bc & C & $n$ & $n$ & \\
\hline & 2006 & -5.5 & -0.6 & 0.3 & 8.4 & 13.7 & 18.2 & 23.5 & 17.7 & 17.1 & 11.7 & 7.2 & 5.8 & 9.8 \\
\hline & $\begin{array}{l}\text { odchylenie } \\
\text { deviation }\left[{ }^{\circ} \mathrm{C}\right]\end{array}$ & $\begin{array}{r}-4.4 \\
\text { ch }\end{array}$ & $\begin{array}{r}-0.3 \\
n\end{array}$ & $\begin{array}{r}-2.5 \\
\text { ch }\end{array}$ & $\begin{array}{r}1.0 \\
\text { IC }\end{array}$ & $\begin{array}{r}1.0 \\
\text { IC }\end{array}$ & $\begin{array}{r}2.2 \\
\text { bc }\end{array}$ & $\begin{array}{r}5.9 \\
\text { ec }\end{array}$ & $\begin{array}{r}0.5 \\
n\end{array}$ & $\begin{array}{r}3.8 \\
\mathrm{ac}\end{array}$ & $\begin{array}{r}2.9 \\
\text { ac }\end{array}$ & $\begin{array}{r}3.4 \\
\text { bc }\end{array}$ & $\begin{array}{r}5.4 \\
\text { ac }\end{array}$ & $\begin{array}{l}1.6 \\
b c\end{array}$ \\
\hline & 2007 & 4.9 & 1.5 & 6.7 & 9.9 & 14.9 & 18.3 & 18.4 & 18.6 & 13.3 & 7.7 & 3.4 & 2.0 & 10.4 \\
\hline & odchylenie & 6.0 & 1.8 & 3.9 & 2.5 & 2.2 & 2.3 & 0.8 & 1.4 & 0.0 & -1.1 & -0.4 & 1.6 & 2.2 \\
\hline & deviation $\left[{ }^{\circ} \mathrm{C}\right]$ & $\mathrm{bc}$ & Ic & $\mathrm{bc}$ & $\mathrm{bc}$ & $\mathrm{bc}$ & $\mathrm{bc}$ & Ic & c & $n$ & Ich & $n$ & Ic & $\mathrm{ac}$ \\
\hline & 2008 & 2.5 & 4.3 & 4.1 & 8.0 & 14.3 & 17.9 & 19.4 & 18.7 & 13.1 & 9.1 & 5.3 & 2.0 & 9.9 \\
\hline & odchylenie & 3.6 & 4.6 & 1.3 & 0.6 & 1.6 & 1.9 & 1.8 & 1.5 & -0.2 & 0.3 & 1.5 & 1.6 & 1.7 \\
\hline & deviation $\left[{ }^{\circ} \mathrm{C}\right]$ & c & c & Ic & $\mathrm{n}$ & Ic & $\mathrm{bc}$ & $\mathrm{c}$ & c & $\mathrm{n}$ & $\mathrm{n}$ & Ic & Ic & $\mathrm{bc}$ \\
\hline & $1961-2000$ & -1.1 & -0.3 & 2.8 & 7.4 & 12.7 & 16.0 & 17.6 & 17.2 & 13.3 & 8.8 & 3.8 & 0.4 & 8.2 \\
\hline \multirow{13}{*}{ 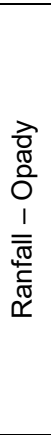 } & 2005 & & & & & & & & & 26 & 20 & 19 & 72 & \\
\hline & the percentage norm & & & & & & & & & 55 & 51 & 46 & 176 & \\
\hline & procent normy & & & & & & & & & $s$ & $\mathrm{~s}$ & bs & sw & \\
\hline & 2006 & 12 & 32 & 33 & 22 & 43 & 23 & 7 & 104 & 38 & 25 & 61 & 27 & 427 \\
\hline & the percentage norm & 34 & 123 & 97 & 58 & 83 & 37 & 10 & 192 & 81 & 64 & 149 & 66 & 79 \\
\hline & procent normy & bs & $\mathrm{n}$ & $\mathrm{n}$ & $\mathrm{s}$ & $\mathrm{n}$ & bs & ss & sw & $\mathrm{n}$ & $\mathrm{s}$ & w & $\mathrm{s}$ & $\mathrm{s}$ \\
\hline & 2007 & 76 & 42 & 54 & 4 & 105 & 109 & 109 & 103 & 47 & & 55 & 34 & 752 \\
\hline & the percentage norm & 217 & 161 & 159 & 11 & 202 & 176 & 163 & 191 & 100 & 36 & 134 & 83 & 140 \\
\hline & procent normy & sw & bw & bw & ss & sw & sw & bw & sw & $\mathrm{n}$ & bs & w & $\mathrm{n}$ & bw \\
\hline & 2008 & 59 & 23 & 46 & 109 & 10 & 30 & 35 & 49 & 47 & 68 & 36 & 40 & 552 \\
\hline & the percentage norm & 168 & 88 & 135 & 287 & 19 & 48 & 52 & 91 & 100 & 174 & 88 & 97 & 103 \\
\hline & procent normy & bw & $\mathrm{n}$ & w & sw & ss & bs & $\mathrm{s}$ & $\mathrm{n}$ & $\mathrm{n}$ & bw & $\mathrm{n}$ & $\mathrm{n}$ & $\mathrm{n}$ \\
\hline & $1961-2000$ & 35 & 26 & 34 & 38 & 52 & 62 & 67 & 54 & 47 & 39 & 41 & 41 & 536 \\
\hline
\end{tabular}

Explanation - Objaśnienia: thermal classification months - termiczna klasyfikacja miesięcy: ec - extremely warm ekstremalnie ciepły, ac - anomalously warm - anomalnie ciepły, bc - very warm - bardzo ciepły, c - warm - ciepły, Ic - lightly warm - lekko ciepły, $\mathrm{n}$ - normal - normalny, Ich - slightly cool - lekko chłodny, ch - cool chłodny; drop classification months - opadowa klasyfikacja miesięcy: ss - extremely dry - skrajnie suchy, bs - very dry - bardzo suchy, s - dry - suchy, $\mathrm{n}$ - normal - normalny, $\mathrm{w}$ - wet - wilgotny, bw - very wet - bardzo wilgotny, sw - extreme wet skrajnie wilgotny.

The temperature of the month was nearly $6^{\circ} \mathrm{C}$ higher than the average, at very low rainfall (10 mm). Deficiencies rainfall persisted since the autumn of 2005, which further worsened the conditions of the growing season, rainfall in 2006 accounted for less than $80 \%$ of normal, so this year was recognized as dry. In 2007, the air temperature was much higher than average, except for the autumn months (IX-XI), but rain in most parts of the year were high, and the months from May to August, even extremely wet. The year 2008 was warmer than normal, and while annual rainfall was close to the average, their distribution was uneven, the worst moisture conditions prevailed in May and June.

\section{RESULTS AND DISCUSSION}

The physical properties of the soil have a major impact on all processes occurring therein. Among the parameters, which have the greatest effect on plant growth, the soil density and stability, as well as system of water and air relations should be listed. The soil density is characterized by two or at least three-phase characteristics, and thus it is variable, different for each soil, increasing as the compacting of the solid phase and simultaneously reducing 
the volume of pores. Cultivation makes that it becomes more plump, the bulk density is lower. Worsening of conditions for plant growth in compacted soils is mainly due to a decrease in porosity and permeability of a soil, reduction in a gas exchange, deterioration of thermal relations, and increase of mechanical resistance (Poniatowska 2003).

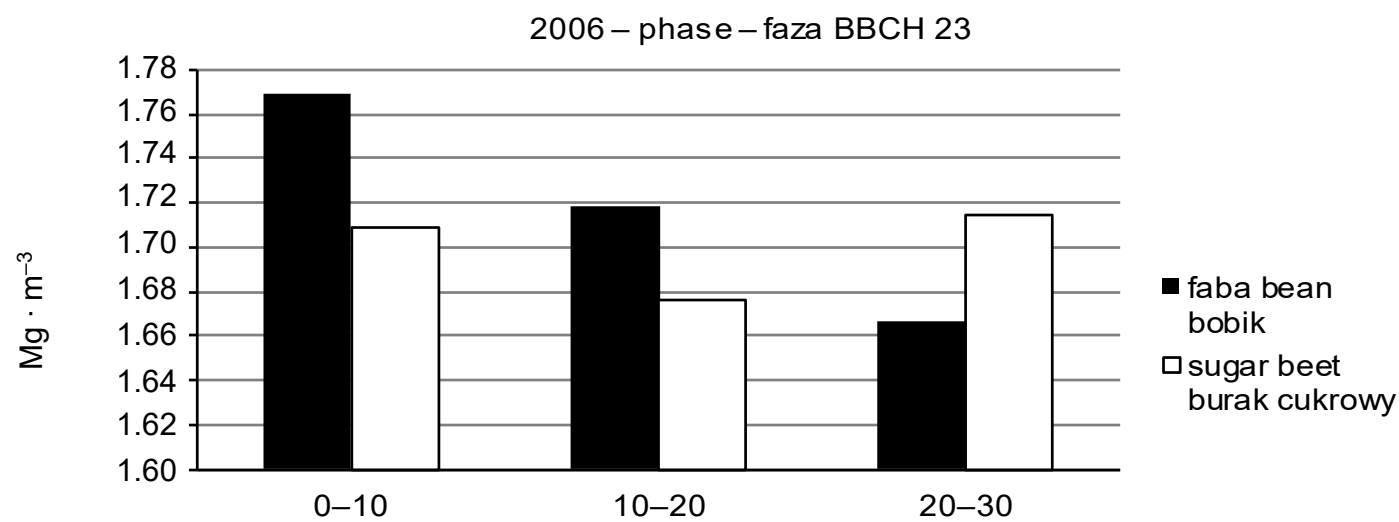

Layer of soil - Warstwa gleby [cm]
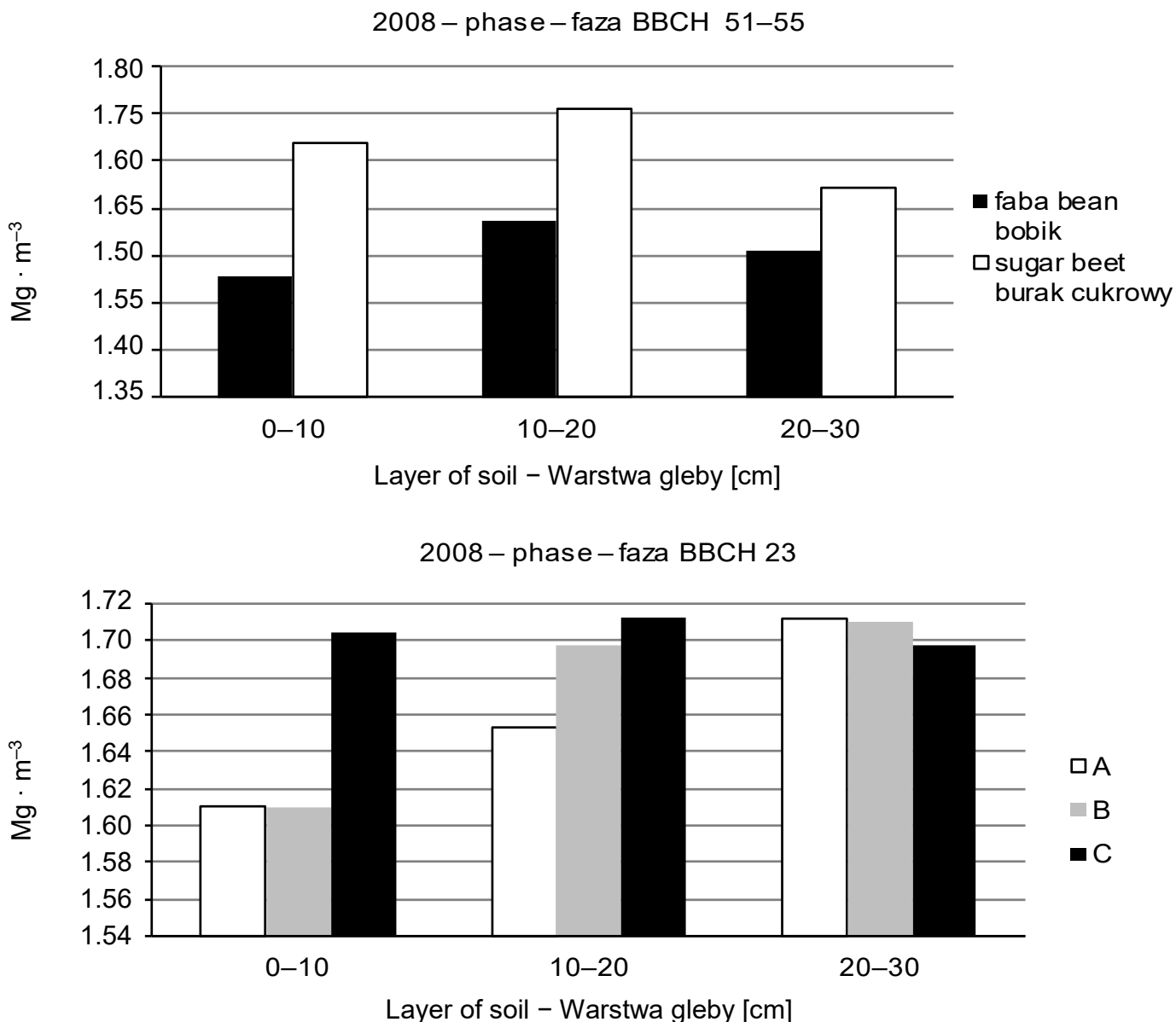

Fig. 1. Effect of previous crop and tillage system on soil bulk density in the growing seasons of winter wheat. A - ploughing, B - ploughless, C - direct sowing

Ryc. 1. Wpływ przedplonu i systemu uprawy na gęstość objętościową gleby w sezonach wegetacji pszenicy ozimej. A - uprawa płużna, B - uprawa bezpłużna, C - siew bezpośredni 
The water-air properties of soil form the water balance and have a decisive impact on the conditions for growth, development, and yielding of plants. They determine the availability of water and air to the plant root system and the movement of water-dissolved nutrients to deeper levels of the soil (Paluszek 2010). Changes in the physical properties of soil, while reducing the intensity of cultivation, are particularly apparent after two or three several-year rotations, especially on light soils (Mcgarry et al. 2000; Je He et al. 2009).

In our study, a significant impact of a forecrop on the soil bulk density was observed in 2006 at the tillering stage, which was the largest in the shallowest layer $(0-10 \mathrm{~cm})$, while in the position after faba bean and sugar beet - in the deepest layer $(20-30 \mathrm{~cm})$. In 2008, both in the position after faba beans and sugar beet, the bulk density was greatest in 10-20 cm layer. Significant impact of cultivation systems was found only in 2008 during the tillering phase. In the traditional and simplified cultivation, this indicator increased along with depth, while in direct sowing - only to a depth of 10-20 cm. It should be noted, however, that bulk density, on average from the three layers of the soil, was the biggest in plots with direct sowing (Fig. 1).

Effect of previous crop on the soil aeration porosity concerned only 2007, the phase of full ripeness. This indicator was significantly higher in all soil layers in the position after sugar beet. Similarly, a significant effect of tillage systems was highlighted in the same year in stages of tillering and full ripeness. Its highest value was recorded in the tillering phase in the simplified system in the shallowest layer $(0-10 \mathrm{~cm})$. In the phase of full ripeness, it concerned the traditional tillage (Fig. 2).

Another characteristics of soil water - total capacity - was significantly shaped only by the forecrop in 2006 in the phase of tillering. This feature was the biggest in the position after sugar beets in 10-20 cm layer. In the position after faba bean, it increased along with soil depth (Fig. 3).

Similarly, only previous crop significantly shaped the current soil moisture (Fig. 4). This was only in 2006 for the tillering and full ripeness phases. In the case of the former trait, the largest humidity was recorded in the position after faba beans in the shallowest layer $(0-10 \mathrm{~cm})$; the humidity decreased along with the depth increasing. A similar response was observed in the phase of full ripeness. In the position after sugar beets during the tillering phase, the greatest current humidity was found in a layer of $10-20 \mathrm{~cm}$, while at full ripeness stage - in 0-10 cm layer.

The last water property evaluated in own study - non-capillary porosity - was significantly shaped by both forecrop and cultivation system. This was in 2006 and 2008. In the first one, this indicator was the highest in the position after sugar beet, both at the tillering and full ripeness stages. In the initial period of growth, it concerned $10-20 \mathrm{~cm}$ layer, while later, the deepest layers $(20-30 \mathrm{~cm})$.

In 2008, a significant impact of a forecrop was found only in the stage of tillering. The greatest non-capillary porosity characterized the layer of $0-10 \mathrm{~cm}$ in the position after faba bean. Along with increasing the depth, value of the indicator decreased to $0.692 \%$ (Fig. 5).

In the case of the tillage systems, their remarkable influence referred only to 2008 , the tillering and full ripeness phases. The largest non-capillary porosity was observed during the tillering phase in traditional cultivation $-1.025 \%$, along with the depth, this parameter decreased up to $0.562 \%$ in the $20-30 \mathrm{~cm}$ layer. In the subsequent vegetation phase - full ripeness - some increase in the non-capillary porosity was recorded for all tillage systems along with the depth increase. It referred to the largest extent to traditional cultivation from the level of $1.475 \%$ in the shallowest to $2.113 \%$ in the $20-30 \mathrm{~cm}$ layer. Results of the water 
management of the soil achieved in the own study for winter wheat were confirmed in the research performed by other authors. Valykis and Satkus (2005) found statistically significant differences in discussed soil properties in the four-field crop rotation system (current moisture content, aeration porosity) in the favor of traditional plowing cultivation. They also reported that spring cereals are more resistant to the stress due to reduced tillage.

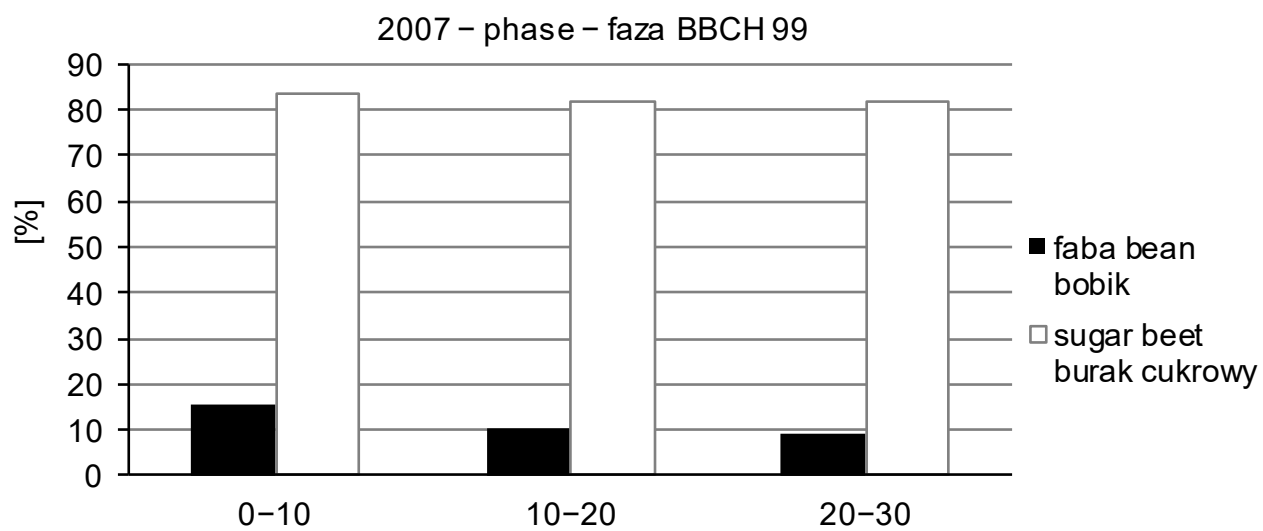

Layer of soil - Warstwa gleby [cm]

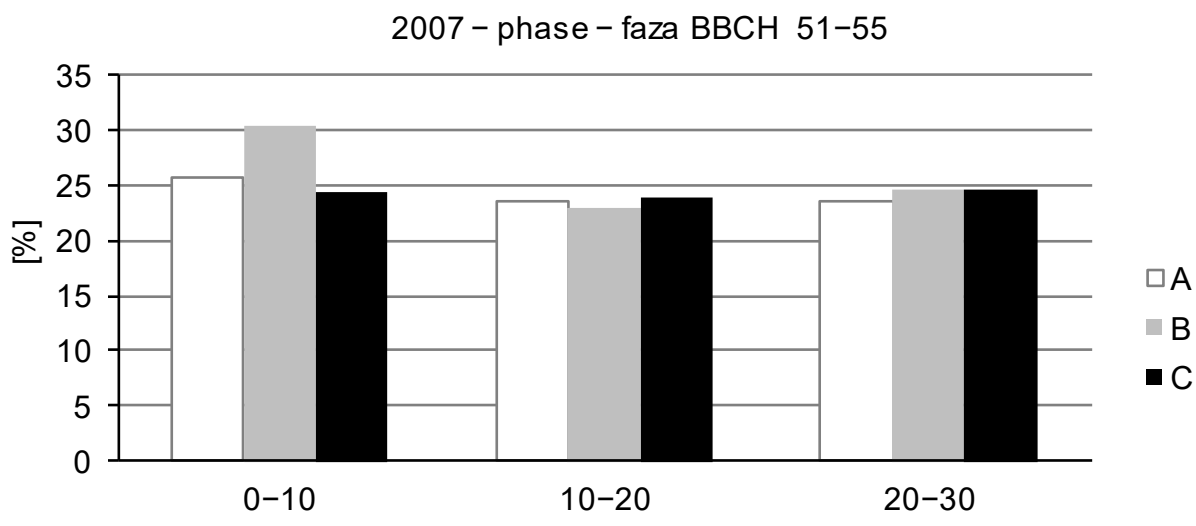

Layer of soil - Warstwa gleby $[\mathrm{cm}]$

2007 - phase - faza BBCH 99

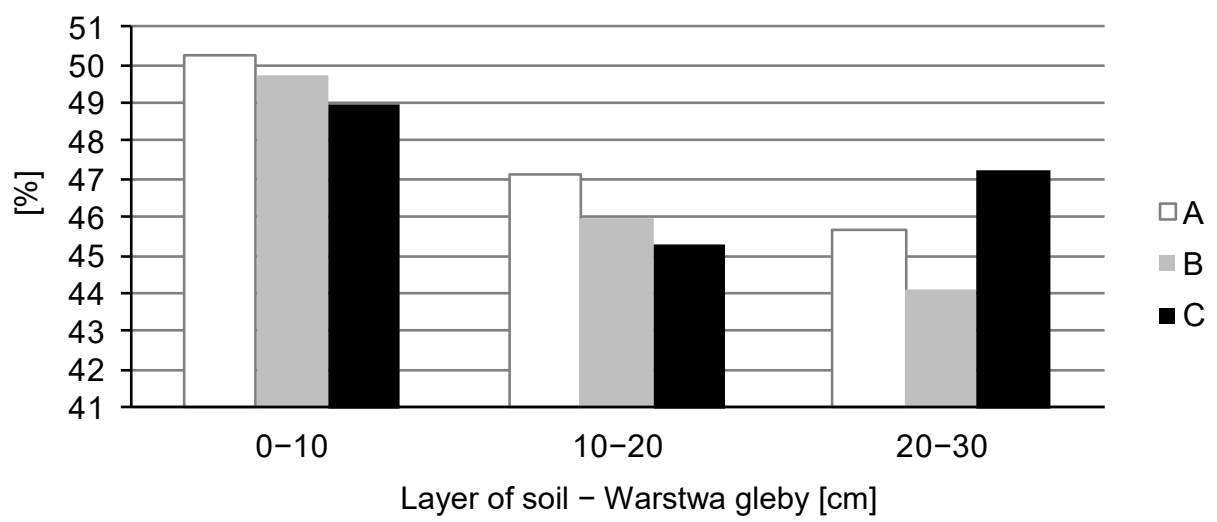

Fig. 2. Effect of previous crop and tillage system on soil aeration porosity in the growing seasons of winter wheat. A - ploughing, B - ploughless, $\mathrm{C}$ - direct sowing

Ryc. 2. Wpływ przedplonu i systemu uprawy na porowatość aeracjną gleby w sezonach wegetacji pszenicy ozimej. A - uprawa płużna, B - uprawa bezpłużna, C - siew bezpośredni 


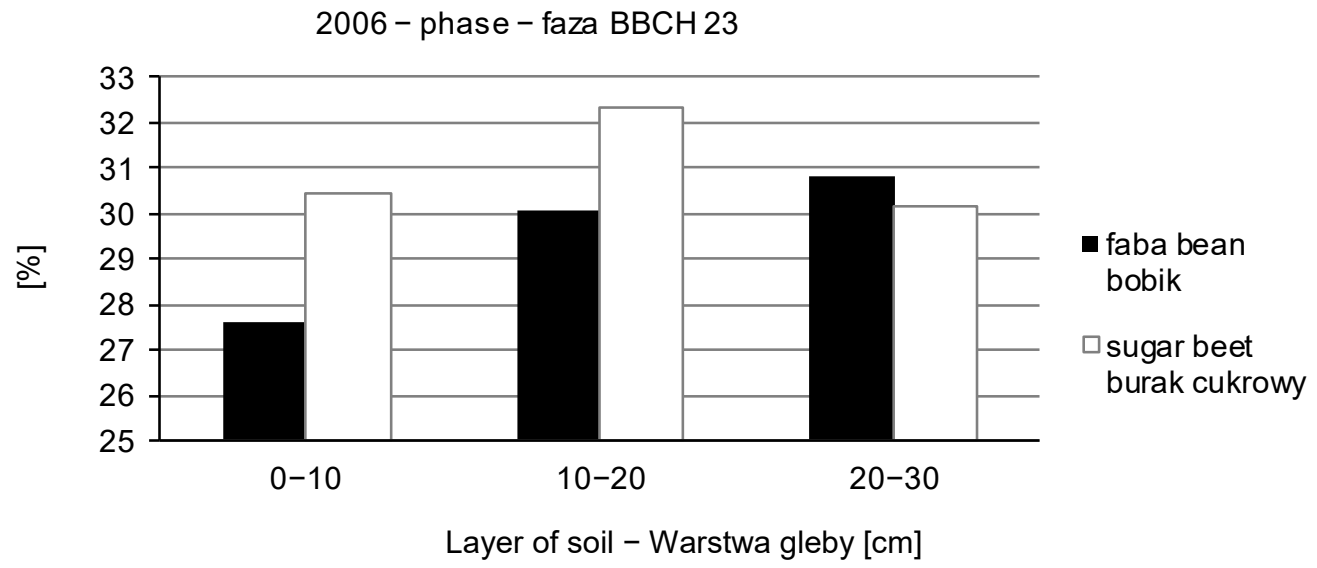

Fig. 3. Effect of the previous crop on the total capacity of the soil in the growing seasons of winter wheat

Ryc. 3. Wpływ przedplonu na pojemność całkowitą gleby w sezonach wegetacji pszenicy ozimej
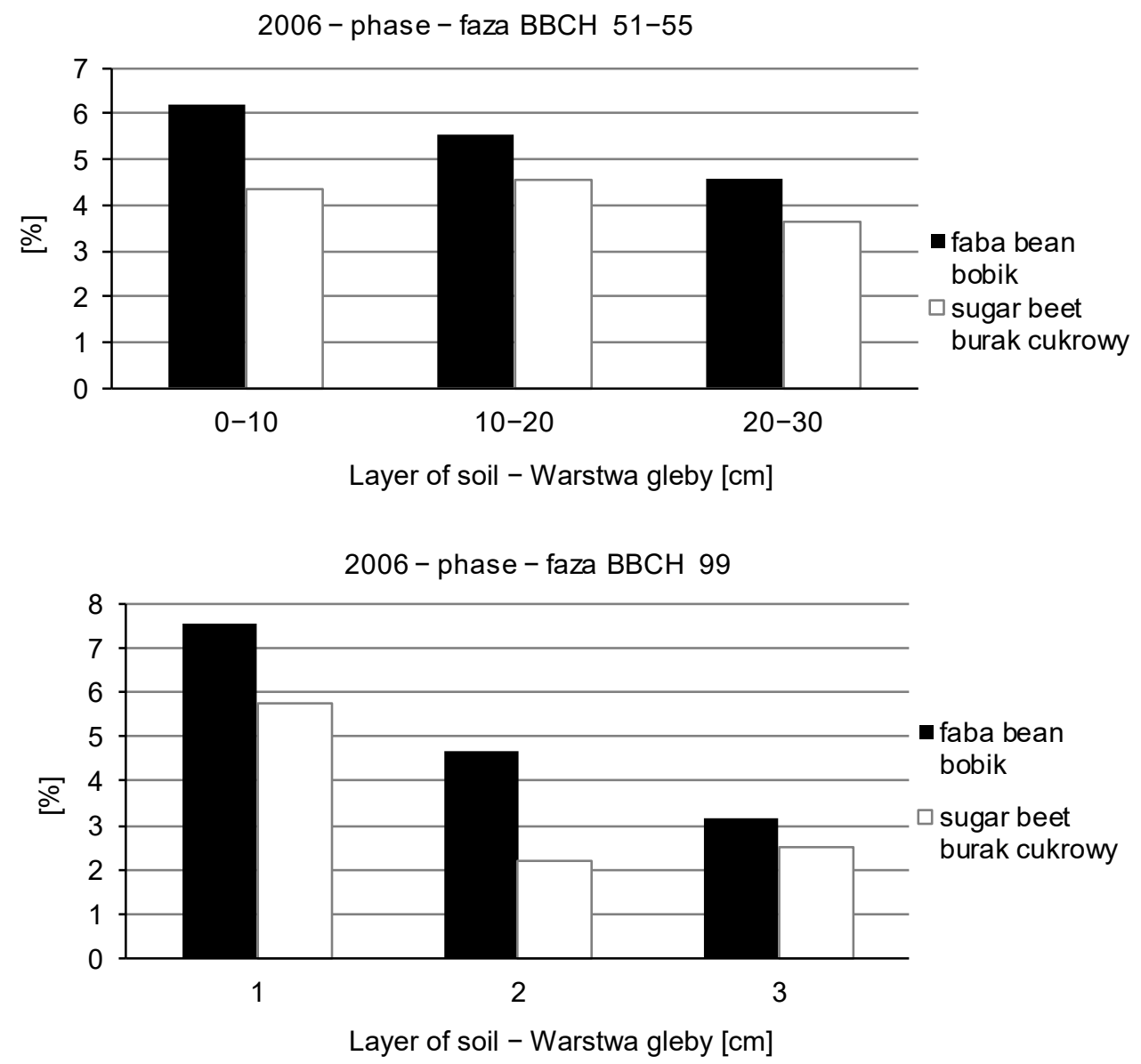

Fig. 4. Effect of previous crop on soil moisture in the growing seasons of winter wheat Ryc. 4. Wpływ przedplonu na wilgotność aktualną gleby w sezonach wegetacji pszenicy ozimej 
2006 - phase - faza BBCH 23

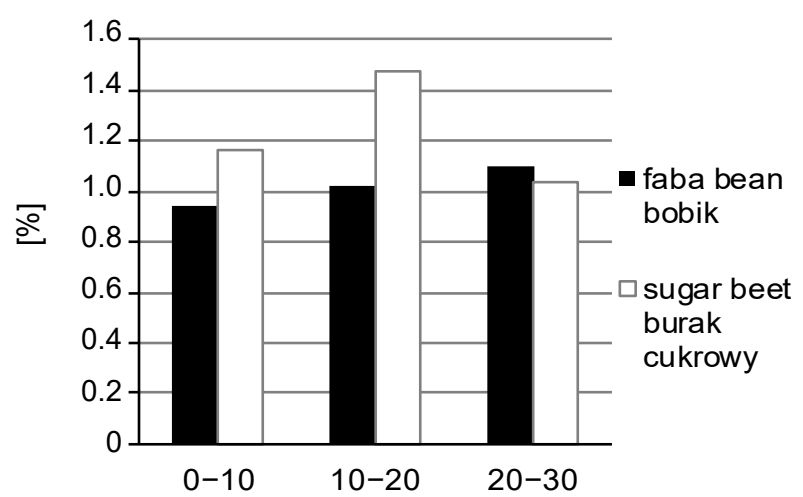

Layer of soil - Warstwa gleby [cm]
2006 - phase - faza BBCH 99

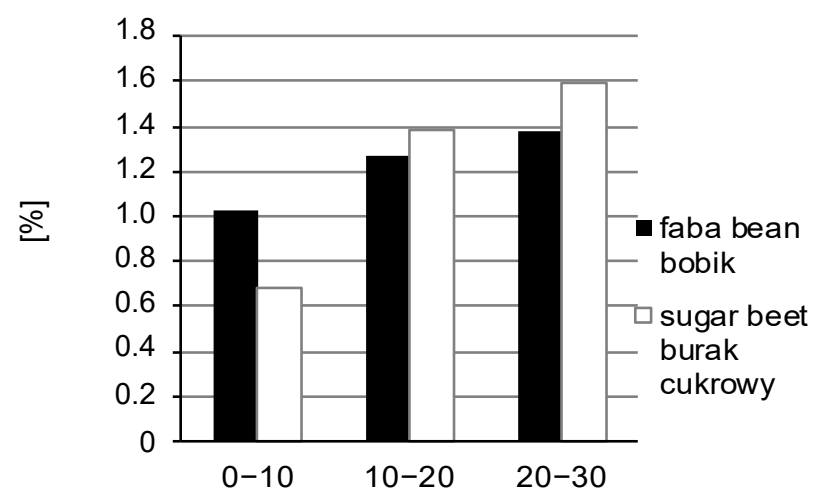

Layer of soil - Warstwa gleby [cm]

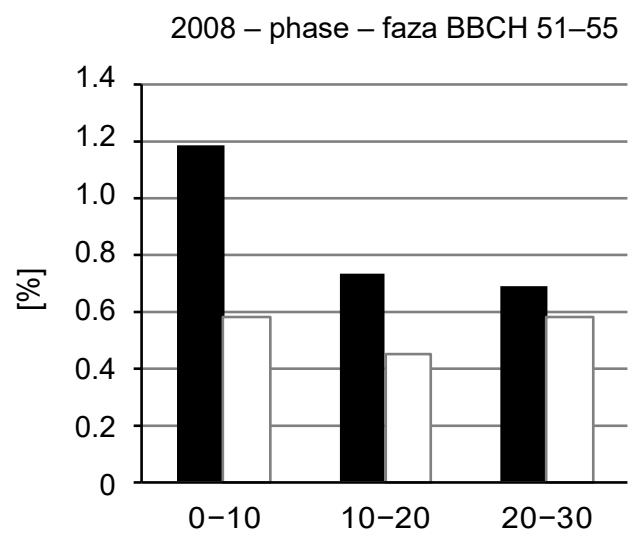

$$
\begin{aligned}
& \text { - faba bean } \\
& \text { bobik } \\
& \square \text { sugar beet } \\
& \text { burak } \\
& \text { cukrowy }
\end{aligned}
$$

Layer of soil - Warstwa gleby [cm]

2008 - phase - faza BBCH 51-55

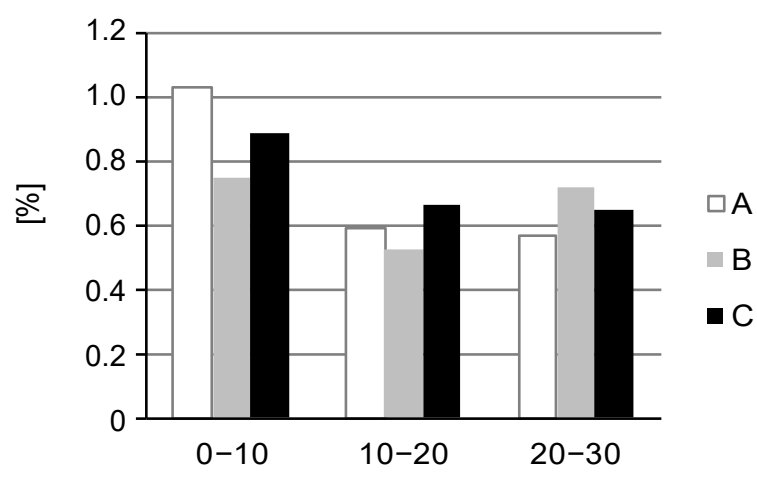

Layer of soil - Warstwa gleby [cm]
2008 - phase - faza BBCH 99

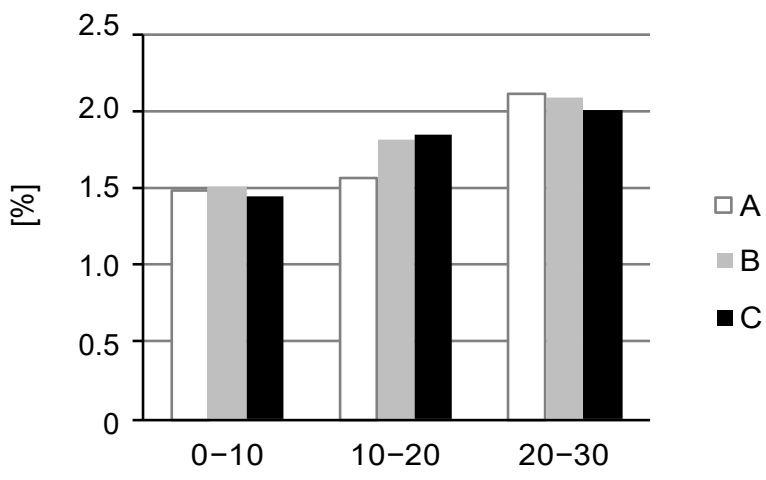

Layer of soil - Warstwa gleby [cm]

Fig. 5. Effect of the previous crop and tillage system on soil porosity noncapilarity in the growing seasons of winter wheat. A - ploughing, B - ploughless, C - direct sowing Ryc. 5. Wpływ przedplonu i systemu uprawy na porowatość niekapilarną gleby w sezonach wegetacji pszenicy ozimej. A - uprawa płużna, B - uprawa bezpłużna, C - siew bezpośredni 
Rucknagel et al. (2004), after 13 years of applying the simplified cultivation systems, concluded that winter cereals give better yields in objects with plowing. Spring cereals better adapt to unfavorable soil conditions with simplified tillage systems. Czyż (2005) found significant differences in the bulk density of soil in favor of the plowing cultivation in $0-25 \mathrm{~cm}$ layer. Ozpinar and Cay (2004), during the field experiments, recorded that under favorable weather conditions, tested physical properties of the soil with different tillage systems had no impact on the level of winter cereals yielding. However, they observed that the $0-30 \mathrm{~cm}$ layer makes better conditions for plants to develop their root system (bulk density and aeration porosity). Czyż and Deuter (2008) statistically proved that simplifications on the crops cultivation improve the water and air balance in heavy soils. Hunsjak et al. (2002) found that the best physical properties of the soil can be found with traditional tillage, slightly worse with the plowless, and the worst with the direct sowing.

\section{CONCLUSIONS}

1. Influence of the forecrop on the light soil physical properties related to the water management, was dependent on the amount of rainfall in the growing season. During the larger shortage of rainfall, the soil in the position after faba bean was characterized by a higher density, current humidity, and non-capillary porosity. In the position after sugar beets, it concerned the aeration porosity. In years with smaller deficiency of rainfall, soil in the position after sugar beet was characterized by increased bulk density, while after faba bean - the non-capillary porosity.

2. Giving up the sowing plow for the surplus of the plowless tillage or direct sowing modifies some physical properties of topsoils. There was an increase in the bulk density and non-capillary porosity.

3. Higher values of bulk density of the soil, listed on the objects, where the applied technologies without plowing, especially on light soils may promote the growth and development of plants commodities, including winter wheat.

\section{REFERENCES}

Blecharczyk A., Małecka I., Skrzypczak G. 2004. Wpływ uproszczonej uprawy roli na plonowanie i zachwaszczenie kukurydzy oraz właściwości gleby [The impact of simplified tillage on yield and weed infestation of maize and soil properties]. Acta Sci. Pol., Agricultura 3(1), 157-163. [in Polish]

Czyż E.A. 2005. Wpływ systemów uprawy roli na wybrane właściwości fizyczne gleby i plonowanie kukurydzy w monokulturze [Effects of tillage systems on some physical properties of soil and yield of maize in monoculture]. Pamięt. Puł. 140, 35-47. [in Polish]

Czyż E.A., Deuter A.R. 2008. Soil physical properties under Winter wheat grown with different tillage systems at selected locations. Inter. Agrophys. 22, 191-200.

Dzienia S., Wereszczaka J. 2002. Energy - effectiveness of varied winter wheat cultivation systems under varied soil conditions. Electron. J. Pol. Agric. Univ., Agronomy 5(1), 8-35, ISSN 1505-0297.

Hryńczuk B., Weber R. 2005. Wpływ uproszczeń w uprawie roli na niektóre właściwości fizyczne gleby [The impact of simplification of tillage on some physical properties of soil]. Rocz. Glebozn. 56(1/2), 77-83. [in Polish]

Hunsjak S., Filipowic D., Kosutić S. 2002. Influence of different tillage systems on soil physical properties and crop field. Rostlina Vyroba 48(6), 249-254. 
Je He, Qingjie Wang, Hongwen Li, Tullberg J.N., McHugh A.D., Yuhua Bai, Xuemin Zhang, McLaughlin N., Huanwen Gao E. 2009. Soil physical properties and infiltration after lon-term no-tillage and ploughing on the Chinese Loess Plateau. New Zeland J. Crop Hortic. Sci. 37(3), 157-166.

Kaczorowska Z. 1962. Opady w Polsce w przebiegu wieloletnim [Precipitation in Poland in the course of many years]. Pr. Geogr. PAN 33. [in Polish]

Kordas L., Klima K. 2005. Wpływ wieloletniego stosowania uproszczeń w uprawie roli i siewu bezpośredniego $w$ uprawie grochu siewnego na właściwości fizyczne gleby [The impact of long-term use of simplifications tillage and direct sowing in cultivation of pea on the physical properties of soil]. Rocz. Glebozn. 56(1/2), 105-111. [in Polish]

Lorenc H. 2000. Termiczno-opadowa ocena klimatycznych sezonów roku w Polsce oraz tendencje czasowo-przestrzenne. Projekt badawczy M-9. Warszawa, IMGW (typescript). [in Polish]

MCgarry D., Bridże B.J., Radford B.J. 2000. Contrasting soil physical properties after zero and traditional tillage of an alluvial soil in the semi-arid subtropics. Soil Till. Res. 53. 105-115.

Ozpinar S., Cay A. 2004. Effect of minimum and conventional tillage systems on soil properties and field of Winter wheat (Triticum aestivum L.) in clay-loam in the Canakkale Region. Turk. J. Agric. 29, 9-18.

Pabin J., Włodek S., Biskupski A. 2002. Oddziaływanie siewu bezpośredniego na wilgotność gleby [The impact of direct sowing on soil moisture]. Post. Nauk Rol. 4, 41-49. [in Polish]

Pabin J., Włodek S., Biskupski A. 2007. Fizyczne właściwości gleby i plony roślin w różnych systemach uprawy roli i ogniwach zmianowania [The physical properties of soil and crop yields in various tillage systems and crop rotation links]. Zesz. Probl. Post. Nauk Rol. 520, 655-661. [in Polish]

Paluszek J. 2010. Kryteria oceny stanu fizycznego gleb płowych wytworzonych z utworów pyłowych [Criteria for assessing the physical condition of soils Luvisols the tracks of dust]. Zesz. Probl. Post. Nauk Rol. 556, 891-896. [in Polish]

Poniatowska J. 2003. Gęstość objętościowa gleb mineralnych i jej znaczenie dla warunków rozwoju roślin [The bulk density of mineral soils and its importance for plant growth conditions]. Rocz. Glebozn. 54(4), 103-113. [in Polish]

Rokosz E., Podsiadło C. 2015. Wpływ deszczowania, system uprawy i nawożenia mineralnego na plonowanie i właściwości fizyczne gleby lekkiej w uprawie odmian bobiku [The impact of irrigation, tillage system and fertilization on yield and soil physical properties of light in the cultivation of varieties of faba Bean]. Infr. Ekol. Ter. Wiej. (3/1), 625-636. [in Polish]

Rucknagel J., Hofmann B., Christem O. 2004. Effect of soil-tillage on soils physical properties, total organic carbon and Winter barley field in long-term experiment in Germany, in: 4 th International Crop Science Congres, Brisbane, Australia 26 September - 1 October 2004. [b.w.]. ISBN 19020842209.

Rudnicki F. 2011. FR-ANALWAR software based on Microsoft Excel, Bydgoszcz, UTP.

Schiller M., Stankowski S. Podsiadło C., Pużyński S., Michalska B. 2017. Rating long-term use simplifications in tillage and previous crop on biometric features, physiological and yield of winter wheat cultivar 'Kobra Plus'. Folia Pomer. Univ. Technol. Stetin., Agric., Aliment., Pisc., Zootech. 332(41)1, 53-62.

Soil taxonomy Polish [Systematyka gleb Polski]. 2011. Rocz. Glebozn.- Soil Sci. Ann. 62(3), 1-193.

Włodek S., Biskupski A., Pabin J. 2007. Plonowanie roślin oraz zmiany retencji wodnej gleby w różnych systemach uprawy roli [Plant yield and changes in soil water retention in different tillage systems]. Inż. Rol. 3(91), 195-200. [in Polish]

Valykis A., Statkus A. 2005. Soil protection value of Winter wheat crops and reduced tillage on Clay loams. Agron. Res. 3(2), 211-218.

Abstract. The study was conducted in a static experiment established in 1993 in the Agricultural Experimental Station in Lipnik (near Stargard Szczeciński). Bi-factorial field experiment was set up in the perpendicular bands pattern of randomized sub-blocks in four replicates. Studied factor consisted of the farming systems used for winter wheat after different forecrops (faba beans, sugar beet). Analysed physical properties, shaping water management 
in light soil, changed depending on the previous crop grown and the amount of rainfall in the growing season. In years with larger rainfall deficits, the soil in the position after faba bean was characterized by a higher density, current humidity, and non-capillary porosity. It referred to the aeration porosity in the position after sugar beet. During years with less rainfall deficiency, the bulk density was increased after sugar beet, while non-capillary porosity decreased after faba bean. Giving up the plowing sowing for the benefit of plowless system or direct sowing modifies some physical properties of topsoils. There was an increase in bulk density and non-capillary porosity. Higher values of bulk density of the soil, listed on the objects, where the applied technologies without plowing, especially on light soils may promote the growth and development of plants commodities, including winter wheat. 